\title{
ARQUEOLOGIA E EDUCAÇÃO: O "PASSADO EXCLUÍDO" DO BRASIL
}

Esta nota visa divulgar alguns trabalhos que estão sendo realizados, já há algum tempo, introduzindo o estudo do Brasil pré-cabralino no cotidiano de crianças e adolescentes, por meio da chamada educação "informal". Antes, porém, é oportuno chamar a atenção para a existência de um "passado excluído" do currículo de ensino brasileiro, apontando brevemente quais são suas principais conseqüências. Por fim, o maior objetivo será mostrar um caminho que deveria ser comum aos pesquisadores da Arqueologia Brasileira: a divulgação de seus trabalhos para além dos limites acadêmicos, proporcionando uma proveitosa união entre a educação (formal e informal) e os trabalhos arqueológicos.

Mackenzie e Stone definiram o "passado excluído" num sentido duplo, podendo encerrar tanto um "passado pré-histórico, que é realmente excluido do currículo ao redor do mundo" quanto "o passado recusado ou omitido de muitos indígenas, minorias ou grupos oprimidos" (Mackenzie \& Stone 1990: 2).

Gestada no Congresso Arqueológico Mundial, realizado em 1986 em Southampton, Inglaterra, a obra de Mackenzie \& Stone (1990) reúne trabalhos de autores do mundo inteiro, que demonstram como o passado é encarado e ensinado nos seus países de origem: trabalhos feitos em pontos diferentes do mundo, mas que, no entanto, demonstram uma uniformidade nos currículos escolares quando se trata de ensinar o passado.

Em trabalho anterior, Mackenzie e Stone (1989) sugeriram quatro grandes razões para existir um "passado excluído" na educação. Em primeiro lugar, os currículos escolares já estão completamente preenchidos, não sobrando espaço para um novo assunto. Em segundo, é ressaltada a própria falta de conhecimento dos professores, adicionada à carência de material apropriado. Terceiro, estudar o passado é geralmente visto como exótico, não tendo relação nenhuma com a sociedade atual. Em quarto lugar, mas não menos verdadeiro, aspectos do passado podem ser excluídos por razões políticas e ideológicas.
Tais razões são verdadeiras para casos no mundo inteiro e, no Brasil, não parece ser de outra maneira. A presente nota divulga um trabalho alternativo que vem sendo realizado com crianças e adolescentes do ensino fundamental e médio, inserindo no cotidiano escolar a questão do "outro". Tal questão é abordada tendo como principal instrumento de aprendizagem a cultura material (tanto etnográfica quanto arqueológica) de culturas "diferentes" que viveram e ainda vivem em nosso país.

Vindo de encontro à necessidade de divulgar esta face excluída do passado brasileiro, o CEIMAM (Centro de Estudos Indígenas "Miguel A. Menéndez") realiza, desde o seu nascimento em 1982, atividades pedagógicas voltadas para um maior conhecimento do passado pré-colonial brasileiro.

Concebido como Projeto de Referência, o CEIMAM $^{1}$ é um centro inter-unidades e interdepartamental da Universidade Estadual Paulista - UNESP. É coordenado pela antropóloga Prof ${ }^{a}$. Dr $r^{2}$. Sílvia Maria S. de Carvalho e conta com a participação de alunos de graduação, principalmente de Ciências Sociais, e pós-graduação (Sociologia, História, Arqueologia, Lingüística, entre outros), além de pesquisadores de diversas áreas do conhecimento, numa perspectiva interdisciplinar, interessados em desenvolver estudos e atividades ligadas à problemática indígena, de forma que as questões emergentes possam ser debatidas entre os próprios membros do centro e a comunidade local, atendendo, assim, a perspectiva acadêmica: ensino, pesquisa e extensão comunitária.

(1) Enquanto centro de pesquisa, tem como objetivo "estudar a adaptação original das comunidades indígenas ao meio, a racionalidade dos seus sistemas adaptativos (de caça-coleta e de horticultura de floresta) e o sucesso dos mesmos na obtenção dos meios de subsistência sem provocar desequilibrios ecológicos. Estudar os problemas decorrentes do contato do índio com o näo-índio, face a sua integração à sociedade nacional. Suprindo, assim, a falta de estudos sistemáticos das sociedades indígenas $e$ visando a formação de futuros pesquisadores" (Regimento Interno, capítulo II, artigo $2^{\circ}$ ). 
O trabalho com alunos do ensino fundamental e médio é desenvolvido por meio de eventos, sendo as principais atividades:

1) Palestras: ex-alunos e professores do CEIMAM abordam, em palestras, discussões relevantes sobre os indígenas atuais, não deixando de fazer referência ao passado desses povos, tão pouco conhecido e geralmente mostrado ao público de forma distorcida. Aliado a esta atividade, conta, também, com um trabalho de orientação e assessoria temática para continuidade das discussões nas escolas envolvidas.

Em importante trabalho especialmente voltado para professores, Neves argumenta que "é uma verdade estabelecida para a maioria dos brasileiros que a história do país foi inaugurada em 22 de abril de 1.500. O que aconteceu antes disso, domínio da 'pré-história', seria um pouco vago e na verdade irrelevante para o posterior desenvolvimento do Brasil, merecendo poucas páginas nos livros didáticos"(Neves 1995:171). O autor ainda ressalta o uso do termo "descobrimento" para designar a ocupação européia, mostrando o preconceito com relação à história dos povos indígenas do Brasil.

Nas palestras, as discussões seguem o propósito de desmistificar esta noção que nos é passada do índio como subjugado e atualmente "aculturado', bem como mostrar quão ultrapassada é a idéia de não haver uma pré-história brasileira que mereça destaque nos currículos escolares.

2) Exibição de Audiovisuais: o CEIMAM também conta com o auxílio de um acervo de vídeos $\mathrm{e}$ slides educativos sobre a história e a atualidade indígenas, que colaboram para ilustrar as diferentes discussões.

3) Exposições Temáticas temporárias e itinerantes: o CEIMAM conta com um acervo Etnográfico e Arqueológico com mais de 600 peças, divididas em Acervo Etnográfico (cerâmica, cestaria/trançados, cordões e tecidos, adorno plumário, instrumentos musicais, armas, objetos rituais, mágicos e lúdicos, utensílios e implementos de madeira), de povos indígenas de todas as partes do país, e Acervo Arqueológico, com uma coleção de artefatos líticos (lascados e polidos) e cerâmica de sítios do Estado de São Paulo, além de uma pequena coleção de fragmentos cerâmicos de sítios da Amazônia brasileira. Além destes, conta ainda com um acervo fotográfico auxiliar.

As diversas exposições realizadas têm a finalidade de apresentar ao público um pouco da história do índio brasileiro através de sua produção material. As exposições de artefatos arqueológi$\cos$, que despertam maior curiosidade nas crianças e no público leigo em geral, exibem as provas de uma remota existência dos índios no Brasil, fazendo nascer uma visão crítica da história geralmente contada nos livros didáticos.

Com o conjunto de recursos didáticos apontados, procura-se mostrar a diversidade cultural existente em nosso país, semeando entre crianças e adolescentes a idéia de respeito pelo diferente. É intuito, também, fazer brotar uma postura crítica nos indivíduos quanto às idéias que são passadas pelos meios de comunicação social (filmes, desenhos, músicas, propagandas, jomais e revistas), em relação aos povos indígenas.

Dentre os principais projetos comunitários, é a "Ameríndia" realizada anualmente no mês de abril, um dos mais significativos. Ao ser posto em prática, por meio de atividades múltiplas (palestras, mesas-redondas, discussões com lideranças indígenas e profissionais das mais diferentes áreas, exposições temáticas, etc.), conduz todos os níveis da formação educacional escolar, além da comunidade local, a debater e entrar em contato com a problemática social indígena.

Trabalhos como o do Centro de Estudos Indígenas $^{2}$ são de grande importância para a propagação de um maior conhecimento sobre os índios brasileiros e sua história, tanto antes do "descobrimento" do Brasil, quanto'na atualidade.

Apesar da falta de verbas para este tipo de atividade, instituições como o CEIMAM, atualmente preocupadas com o caráter pedagógico que trabalhos acadêmicos possam ter, persistem no objetivo de transmitir ao grande público os resultados de seus mais recentes trabalhos. É neste sentido que os arqueólogos têm muito a contribuir para a educação formal e informal, com suas descobertas arqueológicas e teorizações acerca da cultura material. 


\section{Referências bibliográficas}

\section{CEIMAM}

1990 Regimento Interno, SP.

MACKENZIE, R.; STONE, P.

1989 Is There an Excluded Past? D. Uzzel (Ed.) Heritage Interpretation. Londres, Belhaven: 113-120

1990 Introduction: the concept of excluded past. P. Stone; R. Mackenzie (Eds.) The Excluded
Past: Achaeology in education. London, Routledge: 1-14.

\section{NEVES, E.G.}

1995 Os índios antes de Cabral: Arqueologia e História indígena no Brasil. A.L. Silva; L.D.B. Grupioni (Orgs.) A temática indígena na escola. Novos subsídios para professores de 1 e 2 graus. Brasília, MEC/MARI/UNESCO: 171-196.

Robson A. Rodrigues* Solange Nunes de Oliveira**

Recebido para publicação em 28 de janeiro de 1999.

(*) Museu de Arqueologia e Etnologia da Universidade de São Paulo. Mestrando em Arqueologia, bolsista FAPESP e membro do CEIMAM.

(**) Instituto de Filosofia e Ciências Humanas, da UNICAMP. Mestranda em História Social do Trabalho, bolsista do CNPq e membro do CEIMAM. 